ISA

Arboriculture \& Urban Forestry 2015. 41(2): 69-74

\title{
Pruning Severity and Crown Position Influence Aspect Ratio Change
}

\author{
Edward F. Gilman
}

\begin{abstract}
Growth on one branch is suppressed in proportion to pruning severity, resulting in a predictable reduction in branch:trunk diameter (aspect) ratio. However, little is known about response to pruning multiple branches. Several of the largest branches on live oak ( $15.3 \mathrm{~cm}$ trunk diameter) were pruned with four severities $(0 \%, 25 \%, 50 \%$, and $75 \%)$, then branch, nearby stem, and trunk diameter were measured for five subsequent years. Rate of trunk diameter increase five years after pruning was greatest for trees pruned with the $25 \%$ severity. Aspect ratio on all three pruned and measured branches decreased with time after pruning, pruning severity, and increasing height in the crown. Mean aspect ratio ceased declining between three and five years after pruning. The decrease in aspect ratio over time and with increasing severity on pruned branches was less pronounced in the lower crown than in the upper crown. Smaller change in aspect ratio on pruned branches in the lower crown suggests that when structurally pruning trees, branches in the lower crown may require a higher pruning severity to effect the same change in aspect ratio as upper branches.

Key Words. Aspect Ratio; Branch Diameter; Growth Partitioning; Live Oak; Pruning; Pruning Dose; Pruning Severity; Quercus virginiana; Trunk Diameter.
\end{abstract}

Branches with a small aspect ratio (diameter of branch base $\div$ diameter of trunk measured directly above) may resist union failure for several reasons: 1) intermingling of branch and trunk wood fibers in the union (MacDaniels 1932; Shigo 1985); 2) a swirled arrangement of fibers in the union (Slater and Harbinson 2010); 3) a dramatic increase in diameter at the branch base; and perhaps other reasons yet to be discovered. External loads-similar to that of wind, ice, or snow-cause branch breakage beyond the union, instead of in the union on small aspect-ratio branches (Gilman 2003). Branch failure beyond the union serves as a mechanism to protect trunk and union from injuries that would expose them to organisms associated with decay.

This contrasts with the weaker (Kane et al. 2008) parallel and adjacent fiber position when aspect ratio is large, as with a pair of codominant stems. Failure is more likely to occur within the union along the rays than on the branch when the aspect ratio is large (i.e., codominant stems and branches: Miller 1958; Edberg et al. 1994; Gilman 2003). Under certain stresses, rays may be considered a weak point due to the natural crack associated with adjacent living and non-living wood components (Matheck and Kubler 1995). Without the intermingled (MacDaniels 1923) or swirled wood fibers (Slater and Harbinson 2010) associated with stronger unions, excessive bending can result in union failure (Kane and Clouston 2008).

Strength of codominant stem unions can be influenced by the growth history of the two stems that comprise the union. They can be stronger than would be predicted based on their current aspect ratio (Gilman 2003; Kane et al. 2008) because one may have been considerably smaller in diameter than the other in times past, resulting in overlapping and/ or intermingling of wood tissue (MacDaniels 1932). Subsequent stimulation in growth of the smaller component could have brought the current ratio closer to one (i.e., the codominant stem condition).

There is evidence that aspect ratio-and therefore union strength—can be managed with pruning. For example, aspect ratio became smaller on California coastal live oak (Quercus agrifolia N'ee) and valley oak (Q. lobata N'ee) in response to reducing one side of a codominant stem pair (Downer et al. 1994). Growth was slowed on the pruned live oak (Quercus virginiana Mill.) branch in proportion 
to the amount of foliage removed (referred to as pruning severity or dose) resulting in a reduction in aspect ratio (Gilman and Grabosky 2009). There are few studies that include pruning more than one branch or stem in an effort to suppress growth. Kristoffersen et al. (2010) showed that removing no more than about $30 \%$ of secondary branch mass from (an unspecified number of) primary branches from young trees at and/or soon after planting reduced aspect ratio by about $10 \%$ on the lowest two branches over a four-year period. Gilman (2014) induced an eight percent reduction in aspect ratio over a three year period with a single pruning on multiple primary branches at planting. Absent from the literature are studies that pruned with more than one severity on multiple branches which more closely resembles arboricultural practice.

Structural or formative pruning seeks to induce and/or maintain a small aspect ratio on primary branches. It is clear for Quercus virginiana (Mill.) that when one codominant stem is subordinated to slow its growth, the other continues to grow at the pre-pruned rate, or may increase its growth rate (Gilman and Grabosky 2009). The result is a reduction in aspect ratio over time (Downer et al. 1994). However, in practice, several of the largest branches-not just one-are pruned as part of structural pruning (Kristoffersen et al. 2010; Gilman 2014). Therefore, in the lower crown, secondary branches are removed from the portion of the tree to be suppressed (the largest primary branches) as well as from the part of the tree researchers want to grow faster (e.g., the trunk) because additional pruning is performed on primary branches higher in the crown. This study was designed to measure the impact on wood growth partitioning over a five-year period from pruning multiple primary branches on the same tree at $0 \%, 25 \%, 50 \%$, and $75 \%$ pruning severities.

\section{MATERIALS AND METHODS}

Quercus virginiana Mill. is a common tree in USDA hardiness zones $8-10$, and it readily develops codominant stems, which makes it a good subject for study. In July 2008, forty-eight $15.3 \mathrm{~cm}$ trunk diameter (SD $14 \mathrm{~mm}$ ) measured at $30 \mathrm{~cm}$ from ground, $8 \mathrm{~m}$ tall (SD $45 \mathrm{~cm}$ ), 12-year-old, cutting propagated Quercus virginiana Highrise ${ }^{\varpi}$ live oaks planted eight years earlier, $4.9 \mathrm{~m}$ apart, were pruned with the goal of developing one dominant leader.
Trees were located in USDA hardiness zone $8 \mathrm{~b}$ in Millhopper fine sand soil. Pruning was conducted with hand saws by removing branch biomass on the largest aspect ratio primary branches. All pruned primary branch bases and the adjacent trunk above the union were measured with a diameter tape one or two centimeters beyond any swelling associated with the union. Primary branch diameter and aspect ratio were $6 \mathrm{~cm}(\mathrm{SD} \mathrm{1.2)}$ and $0.46(0.1)$, $6 \mathrm{~cm} \mathrm{(1.4)} \mathrm{and} 0.51(0.2)$, and $5 \mathrm{~cm} \mathrm{(1.3)} \mathrm{and} 0.54$ (0.2) for the pruned branch closest to the ground, second lowest, and third lowest, respectively.

Pruning was applied to primary branches with four targeted visual pruning severities (TPS): $0 \%$ (control), $25 \%, 50 \%$, or $75 \%$. Severities were visual estimates of the percentage of foliage removed from the pruned branches. Visual estimates were made by two assessors standing next to the tree as secondary branches were removed. Both assessors had to agree on the severity before pruning was considered complete. In order to establish a more precise measurement of pruning severity, amount of biomass removed from each pruned primary branch was quantified by calculating and summing the crosssectional area (CSA) of each pruning cut (outside bark) from diameter measured with a diameter tape. Ratio of total CSA removed from the primary branch to CSA at the primary branch base where it joined the trunk was termed CSAR, representing a percentage of original primary branch CSA removed. Previous work showed that leaf mass removed was directly related to CSA removed (Grabosky and Gilman 2009). This quantity was used in Equation 1 (Figure 1) to numerically predict percent reduction in aspect ratio. Visual pruning severity estimates were assigned to trees to create a randomized complete block design with 12 blocks (reps) and four adjacent trees per block. One tree chosen at random within each block received one of four severities. All pruned branches on a tree received the same TPS.

One to five (mean $=2$ ) secondary branches were removed from each pruned primary branch to attain the TPS (Table 1); most cuts were reduction cuts and some were removal cuts (Gilman and Lilly 2008). The number of cuts was dictated by the structure on individual trees. One to six primary branches were pruned on each of the 48 trees. The three trees that received cuts on only one or two primary branches had crowns borne primarily on 
two codominant stems; those receiving cuts on five or six primary branches had many codominant stems. The largest diameter, most upright portion of all pruned primary branches that was closest to the leader (trunk) was removed back to a lateral branch using a reduction cut; additional secondary branches were removed as needed on either the retained lateral branch borne at the reduction cut or proximal to the reduction cut to attain TPS. This structural (also called formative) pruning method is described in more detail in Gilman and Lilly (2008). In May 2009, September 2011, and May 2013, basal diameter of pruned primary branches and adjacent trunk above the union on each tree was measured in the manner previously described. Trunk diameter was recorded at each measurement period with a diameter tape at $30 \mathrm{~cm}$ from ground.

Percent reduction in aspect ratio of pruned primary branches was regressed (using SAS Stepwise procedure and factors included when $P<0.05$ ) onto years after pruning (one, three, and five), measured pruning severity (CSAR), and branch ordering (low,
Table 1. Mean number of primary ${ }^{2}$ branches pruned and cuts per branch to achieve targeted pruning severity.

\begin{tabular}{lll}
\hline $\begin{array}{l}\text { Targeted pruning } \\
\text { severity (TPS) }\end{array}$ & $\begin{array}{l}\text { Number of primary } \\
\text { branches pruned per tree }\end{array}$ & $\begin{array}{l}\text { Number of cuts per } \\
\text { branch }\end{array}$ \\
\hline $25 \%$ & $4.1(1.1)^{\mathrm{y}}$ & $1.9(0.9)$ \\
$50 \%$ & $4.1(0.9)$ & $2.2(0.9)$ \\
$75 \%$ & $3.9(1.4)$ & $2.1(0.8)$ \\
\hline
\end{tabular}

${ }^{\mathrm{z}}$ Primary branches are those attached to the trunk.

${ }^{\mathrm{y}}$ Mean (standard deviation).

middle, high); lowest branch was assigned the number one, middle a two, and highest a three. Aspect ratio differences were analyzed by using repeated measures in the mixed model (model = severity, tree(severity), year, severity $\mathrm{x}$ year) within a randomized complete block design using GLM in SAS 9.1.3 (SAS Institute, Cary North Carolina, U.S.) with $P<0.05$. Trunk diameter was analyzed by year with repeated measures one-way analysis of variance in a randomized complete block design with pruning severity as the main effect. Means were compared using Tukey's multiple range test. The three trees with only one or two pruning cuts had missing values for the second and third union, and the third union, respectively.

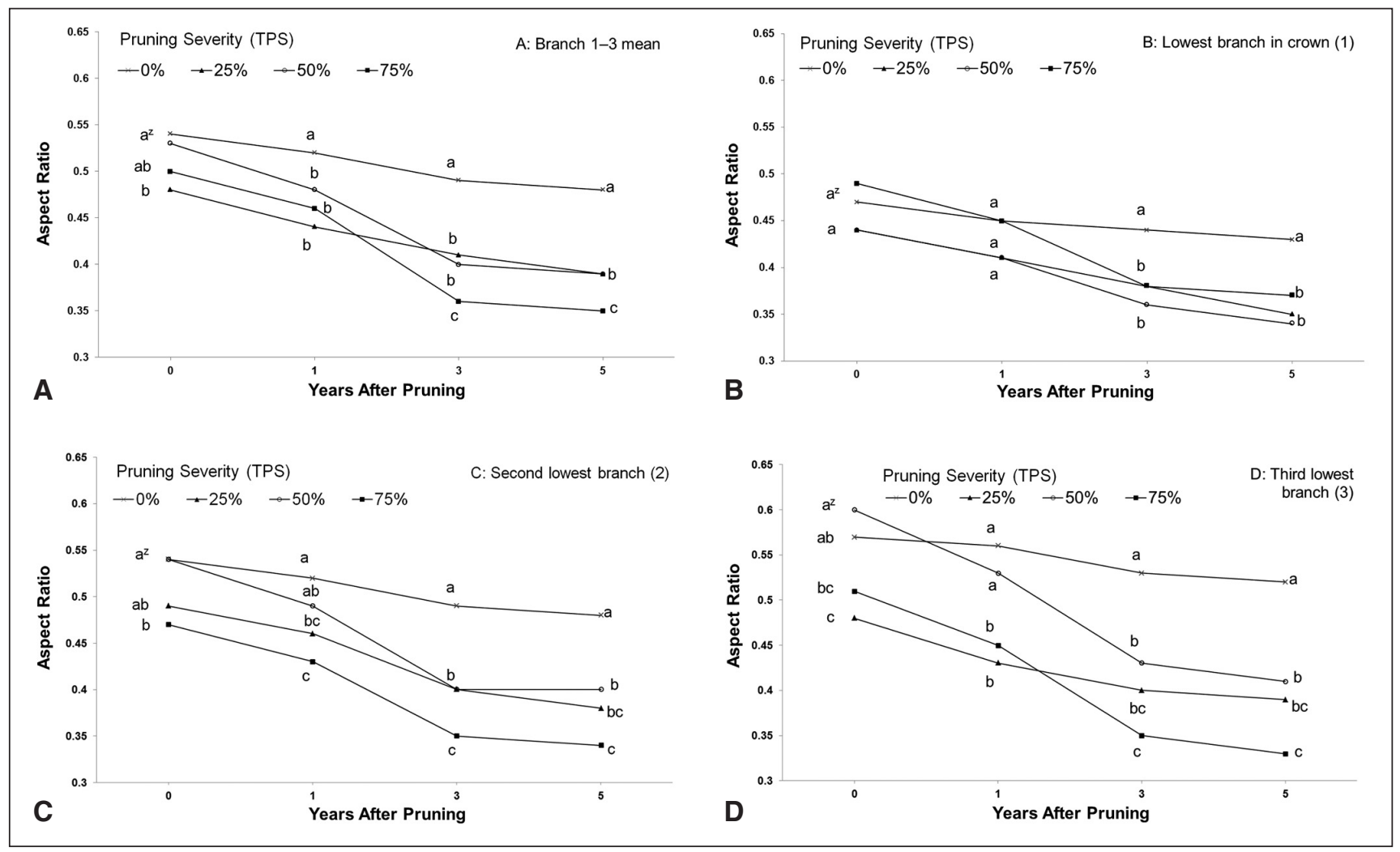

Figure 1. Aspect ratio for the three largest pruned primary branches, and mean aspect ratio one, three, and five years after four pruning severities. Note: ${ }^{2}$ Within each year, different letters indicate a statistical difference among pruning severity at $P<0.05$. Equation 1: Percent reduction in aspect ratio $=2.92$ (branch position) +4.48 (years) +0.17 (CSAR) -0.03 (CSAR removed $\div$ CSA removed from branches above this primary) $-6.19 ; R^{2}=0.38 ; P<0.0001$. 


\section{RESULTS AND DISCUSSION}

Trunk diameter increase the first year after pruning was equivalent for all pruning treatments; by three years after pruning, diameter increase was greater for $25 \%$ TPS than for $75 \%$ TPS with no other differences (Figure 2). By five years after pruning, trees with 25\% TPS experienced more trunk diameter increase than all other treatments, including the non-pruned controls; the remaining treatments were equivalent. Gilman and Grabosky (2009) reported a slight increase in live oak trunk diameter growth at the lowest severity (25\%) with no effect at higher severities (50\% and 75\%) of pruning. Although Stein (1955) and Clark (1955) also found trunk diameter enhancement with light pruning, research on many forest-grown conifers shows either a small reduction or no impact on trunk diameter growth from light crown raising (Hanley et al. 1995). Rate of trunk diameter growth in the present study was not affected-compared to nonpruned controls-despite removing up to $75 \%$ of the foliage from the codominant stem. This might be due to the less than $35 \%$ (estimated) of total foliage on the tree removed with $75 \%$ TPS. These were also young trees; stems of this diameter or larger on older trees may have responded differently.

Trunk diameter growth reportedly slows with increased crown-raising severity (crown-raising pruning method as described in American National Standards Institute (2008), and the effect in the forest can last two or more years (Langstrom and Hellqvist 1991; O’Hara 1991). Supporting this, Rom and Ferree (1985) reported leaf, shoot, root, and total dry weight in the year after pruning peach (Prunus spp.) in an orchard decreased as pruning severity increased. However, there are many reports supporting the lack of, or small impact, as found in the current study. Pruning did not alter trunk diameter or tree height of rose gum (Eucalyptus grandis W. Hill ex Maiden, Bredenkamp et al. 1980), and did not alter crown volume of black walnut (Juglans nigra L., Funk 1979). Neilsen and Pinkard (2003) showed that light crown raising (removing all branches in the lower $45 \%$ of tree height) had no effect on growth of Monterey pine (Pinus radiata D. Don), but heavier pruning ( $60 \%$ or $75 \%$ removal) decreased trunk diameter growth, stem volume, and tree height in the forest. Pinkard and Beadle (1998) reported increased cross-sectional area growth in the tops of forest trees with increased crown-raising severity. Unfortunately, there is little research on growth impacts of raising on open-grown landscape trees. It is not clear whether crown raising that is conducted in the forest relates well to opengrown trees common in arboriculture, but it is one of the only guidelines available in the literature.

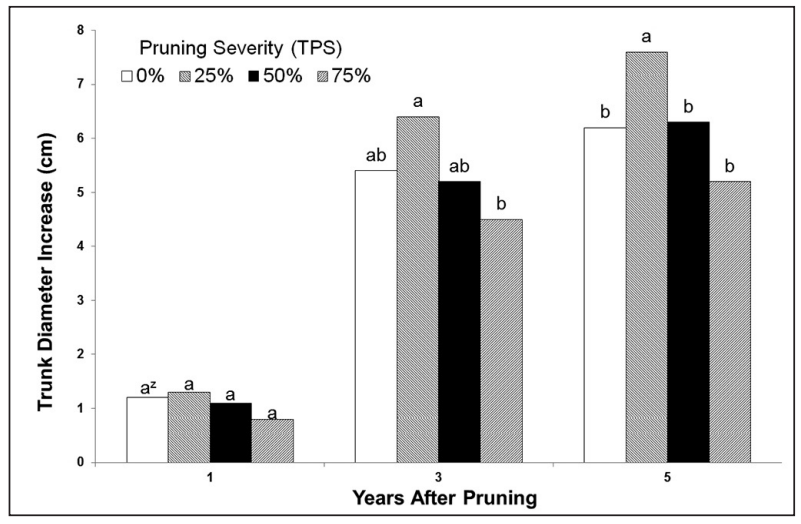

Figure 2. Trunk diameter increase ( $30 \mathrm{~cm}$ from ground) compared to diameter at pruning on trees pruned with different pruning severities. Note: ${ }^{2}$ Within a year, means with different letters are statistically different at $P<0.05$.

Percent reduction in branch aspect ratio increased with years after pruning, pruning severity, and increasing height in the crown (Equation 1, Figure 1). Although mean aspect ratio (Figure 1A) declined by $10 \%$ ( 0.53 versus 0.48 ) over five years without pruning (TPS $=0$ ), pruning at any severity induced a more dramatic decline. Aspect ratio was significantly less on pruned than non-pruned branches one year after pruning, and this difference became more pronounced after three years. Mean aspect ratio ceased declining between three and five years after pruning. The highest pruning severity (75\% TPS) resulted in the smallest ratio three and five years after pruning (Figure 1A). Langstrom and Hellqvist (1991) also found that removing 48\%-75\% of the lower crown by cutting primary branches at the trunk (crown raising) slowed growth for four years on Scots pine (Pinus sylvestris). Continued suppression of aspect ratio far below pre-pruning levels for five years from a single pruning event in the current study suggests that a pruning cycle longer than five years could be used to impact structure on young live oak. Clinical experience suggests this is likely to occur for other taxa as well but should be adjusted as managers gain experience (Gilman et al. 2013). 
Although not tested, a more aggressive program may be needed on trees with a larger aspect ratio.

The decrease in aspect ratio over time and with increasing severity on pruned branches was less pronounced in the lower crown (branch 1) than upper crown (branch 3, Figure 1B, Figure 1C, Figure 1D; Equation 1). This difference became apparent the first year after pruning and persisted through year five, as indicated by the aspect ratio differences among pruning severities in the middle (branch 2) and upper crown (branch 3); there were no differences among the $25 \%, 50 \%$, and $75 \%$ TPS in the lower crown (branch 1). The pruning cuts on primary branches growing from the leader above branch 1 (the lowest measured branch) could explain the smaller change in aspect ratio in branch 1. Essentially, growth slowed on both sides of the union in response to removing branches from both. Smaller change in aspect ratio on pruned branches in the lower crown than in the upper crown suggests that low branches may require a higher pruning severity to effect that same change in aspect ratio as upper branches. The dramatic reduction in growth rate on branch 3 (upper crown) likely occurred because there were few or no pruning cuts (depending on the tree) made on branches originating from the leader above this point. This would largely be in accordance with others who showed a dramatic reduction in growth rate on the pruned stem when no branches were removed from the other side of the union (Downer et al. 1994; Gilman and Grabosky 2009). The dramatic reduction in growth rate on pruned branches in these studies clearly caused the reduction in aspect ratio because there were no pruning cuts made on primary branches higher in the crown.

Gilman (2003), Kane et al. (2008), and others showed that smaller branch:trunk diameter ratios are associated with greater branch union strength. Structural pruning strategies are designed to induce and maintain small ratios. Data from the current study showed that pruning to induce a smaller aspect ratio-as accomplished in other studies by pruning one branch (Gilman and Grabosky 2009) can also be used on multiple branches of the same tree (Kristoffersen et al. 2010). The constriction that occurs within small aspect ratio unions (Eisner et al. 2002) should help trees resist decay organisms moving from branches to trunk. This data suggests that branches in the lower crown should be pruned with a greater severity than those in the upper crown to affect a similar reduction in aspect ratio (Figure 1). Clearly this needs to be studied for a variety of tree types of different ages in different regions.

\section{LITERATURE CITED}

American National Standards Institute. 2008. American National Standard for tree care operations-Tree, Shrub, and Other Woody Pant Maintenance-Standards practices (Pruning). ANSI A300 (part 1). New York: American National Standards Institute.

Bredenkamp, B.V., F.S. Malan, and W.E. Conradie. 1980. Some effects of pruning on growth and timber quality of Eucalyptus grandis in Zululand. South African Forestry Journal 114:29-34.

Clark, F.B. 1955. Black walnut responds to pruning. Journal of Forestry 53:362-365.

Downer, A.J., M. Shaw, and D. Pittenger. 1994. The effect of pruning on branch growth in two oak species. Abstract \#815. HortScience 29:550

Edberg, J., A.M. Berry, and L.R. Costello. 1994. Patterns of tree failure in Monterey pine. Journal of Arboriculture 20:297-304.

Eisner, N.J., E.F. Gilman, J.C. Grabosky, and R.C. Beeson. 2002. Branch junction characteristics affect hydraulic segmentation in red maple. Journal of Arboriculture 28:245-251.

Funk, D.T. 1979. Stem form response to repeated pruning of young black walnut trees. Canadian Journal of Forest Research 9:114-116.

Gilman, E.F. 2003. Branch to stem ratio affects strength of attachment. Journal of Arboriculture 29:291-294.

Gilman, E.F. 2014. Pruning Acer rubrum at planting impacts structure and growth after three growth seasons. Arboriculture \& Urban Forestry 41:11-17.

Gilman, E.F. and S. Lilly. 2008. Best Management Practices Pruning. International Society of Arboriculture. Champaign, Illinois, U.S.

Gilman, E.F., and J. Grabosky. 2009. Growth partitioning three years following structural pruning of Quercus virginiana. Arboriculture \& Urban Forestry 35:281-286.

Gilman, E.F., B. Kempf, N. Matheny, and J. Clark. 2013. Structural pruning: A guide to the green industry. Urban Tree Foundation, Visalia, California, U.S.

Hanley, D.P., C.D. Oliver, D.A. Maguire, D.G. Briggs, and R.D. Fight. 1995. Forest pruning and wood quality of western North American conifers. College of Forest Resources, University of Washington, Seattle, Contribution, No. 77.

Kane, B., and P. Clouston. 2008. Tree pulling tests of large shade trees in the genus Acer. Arboriculture \& Urban Forestry 34:101-109.

Kane, B., R. Farrell, S.M. Zedaker, J.R. Loferski, and D.W. Smith. 2008. Failure mode and prediction of the strength of branch attachments. Arboriculture \& Urban Forestry 34:308-316.

Kristoffersen, P., O. Bühler, S. Ugilt Larsen, and T.B. Randrup. 2010. Growth of newly established roadside trees in response to weed control and pruning. Arboriculture \& Urban Forestry 36:35-40.

Langstrom, B., and C. Hellqvist. 1991. Effects of different pruning regimes on growth and sapwood area of Scots pine. Forest Ecology and Management 44:239-254.

MacDaniels, L.H. 1923. The apple-tree crotch. Cornell Univ., Agric. Exp. Sta. Bull. 419:1-22. 
MacDaniels, L.H. 1932. Factors affecting the breaking strength of apple tree crotches. Abstract, Proceedings American Society for Horticulture Science 29:44.

Matheck, C., and H. Kubler. 1995. Wood-The internal optimization of trees. Springer Vertag, Berlin, Germany.

Miller, V.J. 1958. Crotch influence on strength and breaking point of apple tree branches. Journal American Society Horticulture Science 73:27-32.

Neilson, W.A., and E.A. Pinkard. 2003. Effects of green pruning on growth of Pinus radiata. Canadian Journal of Forest Research 33:2067-2073.

O’Hara, K. 1991. A biological justification for pruning in coastal Douglas-fir stands. Western Journal of Applied Forestry 6:59-63.

Pinkard, E.A., and C.L. Beadle. 1998. Effects of green pruning on growth and stem shape of Eucalyptus nitens (Deane and Maiden) Maiden. New Forests 15:107-126.

Rom, C.R., and D.C. Ferree. 1985. Time and severity of summer pruning influences on young peach tree net photosynthesis, transpiration, and dry weight distribution. Journal of American Society for Horticultural Science 110:455-461.

Shigo, A.L. 1985. How branches are attached to trunks. Canadian Journal of Botany 63:1391-1401.

Slater, D., and C. Harbinson. 2010. Towards a new model of branch attachment. Arboriculture Journal 33:95-105.

Stein, W.I. 1955. Pruning to different heights in young Douglas fir. Journal of Forestry 53:352-355.

\section{Edward F. Gilman \\ Professor \\ University of Florida \\ Environmental Horticulture Department \\ egilman@ufl.edu}

Résumé. La croissance d'une branche est réprimée en proportion avec la sévérité de son élagage, entraînant une réduction prévisible du ratio entre la branche et le diamètre du tronc (aspect). Toutefois, on en sait bien peu sur la croissance réactive suite à l'élagage de multiples branches portées sur un même tronc. Certaines parmi les plus grosses branches de chênes de Virginie, Quercus virginiana, (possédant un tronc avec un diamètre de 15,3 cm) ont été élaguées selon quatre niveaux de sévérité $(0 \%, 25 \%, 50 \%$ et $75 \%)$, puis le diamètre de la branche élaguée, de la branche sous-jacente et du tronc ont été mesurés pendant les cinq années subséquentes. Le taux d'accroissement du diamètre du tronc après cette période a été le plus grand chez les arbres élagués dans une proportion de $25 \%$. Le ratio branche : diamètre du tronc sur toutes les branches élaguées diminuait en lien avec le temps écoulé depuis l'élagage, la sévérité de l'élagage et le positionnement vertical de la branche élaguée dans la ramure. Le ratio branche: diamètre cessait de diminuer entre les troisième et cinquième années suivant l'élagage. La diminution du ratio au fil du temps et avec l'augmentation de la sévérité de l'élagage était moins prononcée sur les branches inférieures de la couronne en rapport avec celles plus élevées dans la couronne. Les plus faibles changements de ratio constatés sur les branches élaguées dans la couronne inférieure suggèrent que lors de l'élagage structural des arbres, les branches inférieures peuvent nécessiter une sévérité d'élagage plus élevée que celles de la couronne supérieure afin d'obtenir un ratio équivalent.
Zusammenfassung. Das Wachstum an einem Ast wird in Relation zum Ausmaß des Rückschnitts unterdrückt, was zu einer vorhersehbaren Reduktion des Ast-:Stammdurchmesserverhältnisses (AspektVerhältnis) führt. Bislang ist wenig bekannt über die Auswirkungen von Rückschnitten multipler Äste. Einige der stärksten Äste einer Lebenseiche (Stammdurchmesser: 15,3 cm) wurden mit vier verschiedenen Stärken $(0 \%, 25 \%, 50 \%$, and $75 \%)$ zurück geschnitten, danach wurden für die folgenden fünf Jahre die Durchmesser von Ästen, benachbarter Stamm und Hauptstamm gemessen. Die Rate des zunehmenden Hauptstammdurchmessers war nach fünf Jahren bei Bäumen mit ca. 25 \% Rückschnitt am größten. Das AspektVerhältnis bei allen drei beschnittenen und gemessenen Ästen sank mit der Zeit nach dem Rückschnitt, dem Ausmaß des Rückschnittes und der zunehmenden Höhe in der Krone. Der Abstieg des mittleren Aspekt-Verhältnisses endete zwischen dem dritten und fünften Jahr nach dem Rückschnitt. Der Abstieg des AspektVerhältnisses über den Zeitraum und mit dem wachsenden Ausmaß des Rückschnittes war bei geschnittenen Ästen in der unteren Krone weniger deutlich als in der oberen Krone. Kleinere Veränderungen im Aspekt-Verhältnis bei geschnittenen Ästen in der Unterkrone verdeutlichen, dass bei strukturiertem Rückschnitt von Bäumen die Äste in der unteren Krone stärker zurück geschnitten werden müssen, um den selben Effekt wie in der oberen Krone zu erzielen.

Resumen. El crecimiento en una rama disminuye en proporción con la severidad de la poda, resultando en una reducción predecible en rama (diámetro en relación con el tronco). Sin embargo, poco se sabe acerca de la respuesta a la poda de ramas múltiples. Varias ramas grandes de un encino (15,3 cm diámetro del tronco) se podaron con cuatro niveles de severidad ( $0 \%, 25 \%, 50 \%$ y $75 \%)$. A continuación la rama, el tallo cercano y el diámetro del tronco se midieron durante los cinco años posteriores. La tasa de incremento del diámetro de tronco cinco años después de la poda fue mayor para los árboles podados con una intensidad del 25\%. La relación de diámetro/tronco en tres ramas podadas disminuyó con el tiempo después de la poda, la severidad de poda y el incremento de la altura de la copa. La relación diámetro/tronco media dejó de disminuir entre tres y cinco años después de la poda. La disminución de la relación diámetro/tronco con el tiempo y con el aumento de la severidad en las ramas podadas fue menos pronunciada en la parte más baja que en la parte superior de la copa. Cambios pequeños en la relación con el tronco en las ramas podadas en la copa inferior sugieren que cuando se podan estructuralmente los árboles, las ramas en la parte inferior de la copa pueden requerir una mayor severidad de poda para efectuar el mismo cambio en las ramas superiores. 